\title{
SOMATINIU巳 DEPRESIJOS SIMPTOMŲ, PASIREIŠKIANČIŲ VYRESNIO AMŽIAUS PACIENTAMS, GYDYMAS
}

\author{
Donatas Savičius \\ Vilniaus universiteto Medicinos fakultetas
}

\begin{abstract}
Raktažodžiai: depresija, somatiniai depresijos simptomai, depresijos senyvame amžiuje gydymas.

Santrauka

Depresija - vienas svarbiausių neigalumą sukeliančių afektinių sutrikimų. Diagnozuoti depresiją vyresnio amžiaus pacientams sunkina esamų sveikatos sutrikimų simptomai, depresijos ir nerimo sutrikimų komorbidiškumas bei depresijos simptomų somatizacija. Somatiniai psichikos sutrikimų simptomai - tai ịvairūs pojūčiai ar skausmas kūne, imituojantys ịvairių organų ar organų sistemų patologiją. Vyresnio amžiaus pacientai, sergantys depresija, sudaro vieną didžiausių grupių, kuriai pasireiškia somatizacija. Šio tyrimo tikslas - jivertinti, susisteminti ir išanalizuoti mokslinėje literatūroje pateikiamus duomenis apie somatinių depresijos simptomų, pasireiškiančių vyresnio amžiaus pacientams, gydymą.
\end{abstract}

\section{Ivadas}

Depresija - vienas svarbiausių neiggalumą sukeliančių afektinių sutrikimų. Diagnozuoti depresiją vyresnio amžiaus pacientams sunkina esančių sveikatos sutrikimų simptomai, depresijos ir nerimo sutrikimų komorbidiškumas bei depresijos simptomų somatizacija, nuo kurios priklauso ir didesnè su depresija susijusio neigalumo rizika [1]. Somatiniai psichikos sutrikimu simptomai - tai ịvairūs pojūčiai ar skausmas kūne, imituojantys įvairių organų ar organų sistemų patologiją. Vyresnio amžiaus pacientai, sergantys depresija, sudaro vieną didžiausių grupių, kuriai pasireiškia somatizacija (tarp vyresnių, nei 60 metų pacientų $\sim 98$ proc. skundžiasi somatiniais simptomais) ir aukštas komorbidiškumas (tarp vyresnių, nei 60 metų pacientų $\sim 72$ proc. tuo pačiu metu kenčia nuo generalizuoto nerimo sutrikimo) [2]. Tokie pacientai dažniausiai skundžiasi apetito ir svorio sumažejimu, bendru silpnumu, miego sutrikimais, ịvairiais skausmais [3]. Tiriant vyresnio amžiaus pacientus, buvo nustatyta, kad didžioji dalis sergančiujų depresija pažymi tik somatinius simptomus, o pusei iš jų anksčiau buvo nustatytos kitos diagnozès dèl išreikštų fizinių (somatinių) simptomų, nesant tipinių depresijos klinikinių požymių [4].
Tyrimo tikslas - išanalizuoti bei aptarti ịrodymais pagristą informaciją apie somatinių depresijos simptomų, pasireiškiančių vyresnio amžiaus pacientams, gydymą.

\section{Tyrimo medžiaga ir metodai}

Taikyta sisteminè mokslinès literatūros bei dokumentų apžvalga ir analizè. Duomenų buvo ieškoma Google Scholar, UpToDate, Cochrane bei Medline (PubMed) duomenų bazèse. Visateksčiai straipsniai atrinkti, jei jų pavadinimas, santrauka ar reikšminiai žodžiai nurodè, kad tyrimas tinkamas ịtraukti ị šią apžvalgą. Pasirinktos tik anglų kalba skelbtos publikacijos. Vartoti nurodyti raktažodžiai. Atrinkti, išanalizuoti ir apibendrinti 12 straipsnių.

\section{Tyrimo rezultatai}

Atliktų tyrimų duomenimis, naudojant ịprastinị 6-8 savaičų trukmès gydymo kursą antidepresantais, tik mažai daliai pacientų, esant išreikštiems somatiniams simptomams, buvo pasiekta visiška remisija [5]. Somatinių simptomų išlikimas susijęs su padidejjusia ligos atkryčio ir tolimesnio neiggalumo rizika, suprastėjusia gyvenimo kokybe. Lyginant antidepresantų pasirinkimą ūminès gydymo fazès metu, selektyvūs serotonino rezorbcijos inhibitoriai (SSRI), puikiai tinkantys psichologinių simptomų gydymui, somatiniams simptomams turejo tokią pat itaką, kaip placebas [6]. Serotonino ir noradrenalino reabsorbcijos inhibitoriai (SNRI) duoda gerus somatiniu depresijos simptomų gydymo rezultatus, stebima greita remisija ir mažesnè atkryčio rizika [7]. Gydymo efektyvumas priklauso nuo serotonino ir noradrenalino receptoriu veikimo tuose neuronų tinkluose, kurie atsakingi už somatinių simptomų atsiradimą. Siekiant sumažinti nuovargio pasireiškimą, buvo siūloma papildomai skirti modafinili, bupropioną ar selektyvius noradrenalino rezorbcijos inhibitorius, tačiau trūksta duomenu dèl jų efektyvumo [8]. Kitos siūlomos somatinių simptomų gydymo priemonès - kognityvine elgesio psichoterapija ir elektrokonvulsinè terapija [9]. Šie gydymo metodai yra efektyviai naudojami rezistentiškos depresijos ir somatoforminiu sindromų gydymui. Elektrokonvulsinès terapijos naudojimas rekomenduojamas somatinių simptomų gydymui, ypač tais 
atvejais, kai pasireiškia kartu su depresija ir savižudybès idèjomis $[10,11]$. Šio gydymo metodo taikymas yra naudingas gydant pacientus su išreikštais somatiniais virškinimo sistemos simptomais, tačiau dèl platesnių elektrokonvulsinès terapijos galimybių vyresnio amžiaus pacientams dar trūksta duomenų [10].

Kognityvinès elgesio terapijos klinikiniai tyrimai, atlikti su vyresnio amžiaus pacientais, sergančiais depresija ir patiriančiais somatinius simptomus, įrodè, kad 15 savaičių trukmès psichoterapijos kursai yra pakankamai efektyvus palaikomojo gydymo būdas, mažinantis atkryčių riziką ir paspartinantis somatinių simptomų remisiją [12]. Nors psichoterapija turi teigiamų ilgalaikių rezultatų gydant sunkią ir gydymui rezistentišką depresiją, pacientai turi būti motyvuoti psichoterapijai ir turi turèti galimybę gauti jiems tinkamą pagalbą.

\section{Išvados}

1. Vyresnio amžiaus pacientai, sergantys sunkia depresija, kuriems kartu pasireiškia somatiniai simptomai, yra atsparesni medikamentiniam gydymui.

2. Vyresnio amžiaus pacientų gydymas tik antidepresantais gali būti nepakankamas visiškai remisijai pasiekti. Tokiais atvejais reikia svarstyti papildomą kognityvinès elgesio psichoterapijos ar kitų nemedikamentinių gydymo priemonių naudojimą.

3. Gydant sunkią depresiją, siekiama visiškai išgydyti somatinius simptomus, nes jų išlikimas susijęs su daug didesne depresijos atkryčio rizika.

\section{Literatūra}

1. Morin RT, Nelson C, Bickford D, Insel PS, Mackin RS. Somatic and anxiety symptoms of depression are associated with disability in late life depression. Aging \& Mental Health 2019;0(0):1-4. https://doi.org/10.1080/13607863.2019.1597013

2. Grover S, Sahoo S, Chakrabarti S, Avasthi A. Anxiety and somatic symptoms among elderly patients with depression. Asian Journal of Psychiatry 2019;41:66-72. https://doi.org/10.1016/j.ajp.2018.07.009

3. Cheprasov A. What are somatic symptoms of depression? https:// study.com/academy/lesson/what-are-somatic-symptoms-ofdepression.html

4. Wang Y, He Y, Wang G, Li J, Zhu H. Correlation analysis between attentional bias and somatic symptoms in depressive disorders. Front Psychiatry 2019;10. https://doi.org/10.3389/fpsyt.2019.00903

5. Kapfhammer H-P. Somatic symptoms in depression. Dialogues Clin Neurosci 2006;8(2):227-39. https://doi.org/10.31887/DCNS.2006.8.2/hpkapfhammer

6. Schalet BD, Tang TZ, DeRubeis RJ, Hollon SD, Amsterdam JD, Shelton RC. Specific pharmacological effects of paroxetine comprise psychological but not somatic symptoms of depression. PLoS One 2016;11(7). https://doi.org/10.1371/journal.pone.0159647

7. Barkin RL, Barkin S. The role of venlafaxine and duloxetine in the treatment of depression with decremental changes in somatic symptoms of pain, chronic pain, and the pharmacokinetics and clinical considerations of duloxetine pharmacotherapy. Am J Ther 2005;12(5):431-8. https://doi.org/10.1097/01.mjt.0000162011.58990.94

8. Fava M. Pharmacological approaches to the treatment of residual symptoms. J Psychopharmacol (Oxford). 2006; 20(3 Suppl):29-34.

https://doi.org/10.1177/1359786806064325

9. Richard N. Psychotherapy for depressive disorders. In: AbdElsayed A, editor. Pain: a review guide. Cham: Springer International Publishing 2019; 397-9. https://doi.org/10.1007/978-3-319-99124-5 88

10. Reinemann J, Phillips L, Gentry M, Lapid M. ECT for the treatment of somatic symptom disorder and unintentional weight loss in older adults: 2 case reports. The American Journal of Geriatric Psychiatry 2020;28(4, Supplement):S59-60. https://doi.org/10.1016/j.jagp.2020.01.090

11. Borisovskaya A, Augsburger JA. Somatic symptom disorder treated with electroconvulsive therapy. Pain Management 2016;7(3):167-70. https://doi.org/10.2217/pmt-2016-0048

12. Hummel J, Weisbrod C, Boesch L, Himpler K, Hauer K, Hautzinger $\mathrm{M}$, et al. AIDE-acute illness and depression in elderly patients. Cognitive behavioral group psychotherapy in geriatric patients with comorbid depression: a randomized, controlled trial. Journal of the American Medical Directors Association 2017;18(4):341-9.

https://doi.org/10.1016/j.jamda.2016.10.009

\section{TREATMENT OF SOMATIC SYMPTOMS OF DEPRESSION IN ELDERLY PATIENTS D. Savičius}

Keywords: depression, somatic symptoms of depression, treatment of depression in elderly.

Summary

Depression is one of the most prevalent disability causing affective disorders. It is difficult to diagnose depression in elderly patients due to symptoms of pre-existing health problems, comorbidity of depression and anxiety, as well as somatization of symptoms of depression. Somatic symptoms of psychiatric disorders include various sensations or pain, imitating other organic pathology. Elderly patients with depression exhibit major prevalence of somatization. The aim of this study was to evaluate, systematize and analyze the data presented in the scientific literature on treatment of somatic symptoms of depression in elderly patients.

Conclusions. Elderly patients with major depression, exhibiting somatization of symptoms are more resistant to pharmacological treatment. Antidepressants alone may be insufficient to reach remission in elderly patients. Cognitive behavioral therapy and other non-pharmaceutical methods of treatment should be considered. In case of major depression, goal of treatment is complete remission of somatic symptoms to minimize risk of relapse.

Correspondence to: donatassavicius@gmail.com

Gauta 2021-04-25 